\title{
(2) OPEN ACCESS \\ Pulmonary artery sling: a rare cause of stridor and respiratory distress
}

\author{
Nádia Santos, ${ }^{1}$ Teresa Almeida, ${ }^{1}$ Maria Carlos Janeiro (i), ${ }^{2}$ Duarte Martins $\left({ }^{3}\right.$
}

${ }^{1}$ Department of Pediatrics, Hospital do Espirito Santo EPE, Evora, Portugal ${ }^{2}$ Department of Pediatrics, Hospital Professor Doutor Fernando Fonseca EPE, Amadora, Lisboa, Portugal ${ }^{3}$ Paediatric Cardiology, Centro Hospitalar de Lisboa Ocidental EPE, Lisboa, Portugal

\section{Correspondence to}

Dr Nádia Santos;

nadiasantos15@hotmail.com

Accepted 29 January 2020

\section{DESCRIPTION}

A newborn boy, late preterm, with an uneventful pregnancy, presented with stridor and a systolic murmur since birth. A neonatal transthoracic echocardiogram revealed a patent ductus arteriosus and ostium secundum atrial septal defect. During the first year of life, he presented recurrent respiratory distress, cough, wheezing, stridor and multiple respiratory infections. For more than once, he required non-invasive respiratory support. Daily medication included inhaled steroids and montelukast but with poor response. He had an adequate development and physical growth, without feeding problems. A bronchoscopy was performed and a right distal tracheobronchial stenosis was identified.

At 18 months old, he was referenced to a tertiary paediatric cardiology centre, after the CT angiography showed an anomalous origin of the left pulmonary artery (LPA). The LPA originated from the proximal right pulmonary artery, coursing over the right mainstem bronchus, posterior to the distal trachea and anterior to the oesophagus, causing an airway compression (figures 1 and 2).

He underwent surgical repair of the pulmonary artery sling (PAS) by median sternotomy. The LPA was repositioned to the left side of the main pulmonary artery, in the correct anatomical position, and the ductus arteriosus was ligated, under cardiopulmonary bypass, without tracheoplasty.

Postoperative bronchoscopy showed an improvement in the distal trachea caliber, without inspiratory collapse and incomplete cartilaginous rings. He was extubated on the first postoperative day showing a regression of the stridor, despite persistent respiratory distress. The patient was discharged 8 days

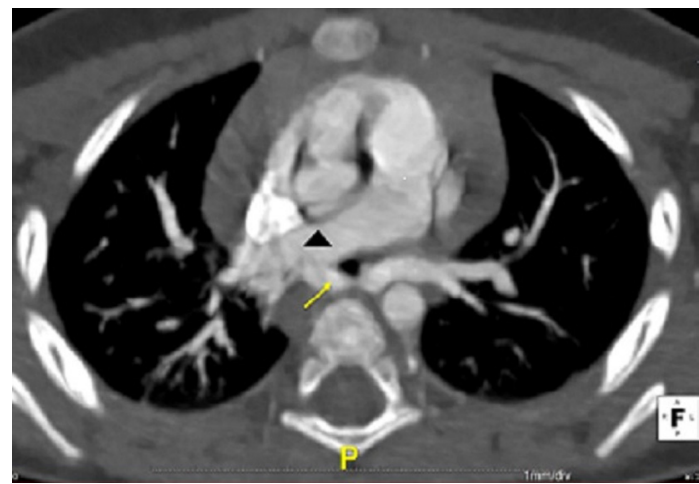

Figure 1 Transverse CT image after intravenous administration of iodinated contrast confirms the diagnosis of left pulmonary artery sling (LPAS; yellow arrow) arising from the right pulmonary artery (arrowhead).

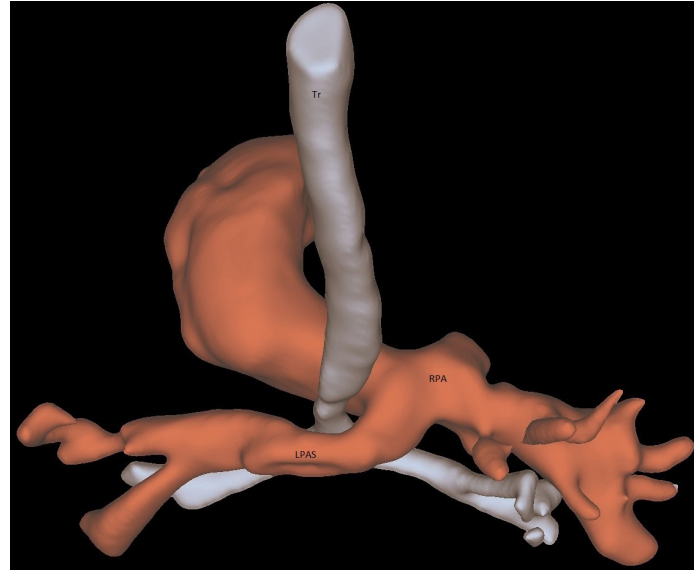

Figure 2 A 3D-reconstructed CT image (posterior view) shows LPAS arising from the right pulmonary artery (RPA) crossing behind the trachea ( $\mathrm{Tr}$ ) causing stenosis. LPAS, left pulmonary artery sling.

after surgery and maintained a regular follow-up with an improvement of respiratory symptoms.

This rare form of vascular ring is known as PAS, which has an estimated prevalence of 59 per million school-aged children, but it is an underdiagnosed condition or misdiagnosed as respiratory pathology. ${ }^{1}$ Paediatricians must be aware of this cause of respiratory distress and have a high clinical suspicion index. It is associated with respiratory symptoms in the first year of life, due to tracheal stenosis, which can be life-threatening. ${ }^{1-3}$ Patients with tracheomalacia, recurrent or persistent stridor and/or wheezing should be evaluated for vascular rings, to allow an early diagnosis and timely surgical intervention, in order to avoid morbidity and mortality in children.

Retrospectively, the chest X-rays showed a narrowing and right indentation of the distal trachea (figure 3), which might have suggested the diagnosis.

Although echocardiography may be a helpful imaging tool, it is sometimes insufficient to establish this diagnosis due to its low sensitivity. ${ }^{2}$ CT angiography is the gold standard imaging technique providing not only an accurate diagnostic evaluation but also the best guidance for the surgical approach. ${ }^{3}$

Associated cardiovascular malformations are frequent, with a reported prevalence of up to $50 \% .^{3}$ This includes patent ductus arteriosus, which may contribute to encirclement of the trachea.

In symptomatic patients, the early reimplantation of the LPA to the anatomic position is effective. The 


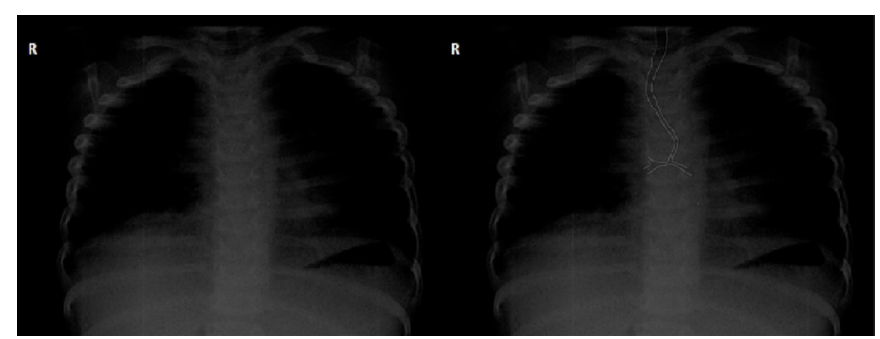

Figure 3 Chest X-rays show a narrowing and right indentation of the distal trachea.

clinical outcome is generally good, depending mostly on associated tracheal or/and cardiac anomalies.

\section{Learning points}

- Patients with recurrent and/or prolonged stridor and wheeze should be examined for the possible presence of vascular rings and slings, such as pulmonary artery sling.

- There must be a high degree of clinical suspicion regarding this diagnosis because it is a rare cause of respiratory distress.

- CT angiography is the gold standard imaging technique. Early surgical management in symptomatic patients is effective.

Contributors NS: substantial contributions to the conception or design of the work, or the acquisition, analysis or interpretation of data. Drafting the work and revising it critically for important intellectual content. Final approval of the version published. Agreement to be accountable for all aspects of the work in ensuring that questions related to the accuracy or integrity of any part of the work are appropriately investigated and resolved. TA: substantial contributions to the conception or design of the work, or the acquisition, analysis or interpretation of data. Drafting the work. Final approval of the version published. Agreement to be accountable for all aspects of the work in ensuring that questions related to the accuracy or integrity of any part of the work are appropriately investigated and resolved. MCJ, DM: revising it critically for important intellectual content. Final approval of the version published. Agreement to be accountable for all aspects of the work in ensuring that questions related to the accuracy or integrity of any part of the work are appropriately investigated and resolved.

Funding The authors have not declared a specific grant for this research from any funding agency in the public, commercial or not-for-profit sectors.

Competing interests None declared.

Patient consent for publication Parental/guardian consent obtained.

Provenance and peer review Not commissioned; externally peer reviewed.

Open access This is an open access article distributed in accordance with the Creative Commons Attribution Non Commercial (CC BY-NC 4.0) license, which permits others to distribute, remix, adapt, build upon this work non-commercially, and license their derivative works on different terms, provided the original work is properly cited and the use is non-commercial. See: http://creativecommons.org/ licenses/by-nc/4.0/

\section{ORCID iDs}

Maria Carlos Janeiro http://orcid.org/0000-0003-2245-5738

Duarte Martins http://orcid.org/0000-0003-0662-5629

\section{REFERENCES}

1 Yu J-M, Liao C-P, Ge S, et al. The prevalence and clinical impact of pulmonary artery sling on school-aged children: a large-scale screening study. Pediatr Pulmonol 2008;43:656-61.

2 Delacour D, Demeyere M, Dubourg B, et al. Left pulmonary artery sling: a rare cause of congenital stridor. Diagn Interv Imaging 2017;98:85-7.

3 Xie J, Juan Y-H, Wang Q, et al. Evaluation of left pulmonary artery sling, associated cardiovascular anomalies, and surgical outcomes using cardiovascular computed tomography angiography. Sci Rep 2017;7:1-10.

Copyright 2020 BMJ Publishing Group. All rights reserved. For permission to reuse any of this content visit

https://www.bmi.com/company/products-services/rights-and-licensing/permissions/

BMJ Case Report Fellows may re-use this article for personal use and teaching without any further permission.

Become a Fellow of BMJ Case Reports today and you can:

- Submit as many cases as you like

- Enjoy fast sympathetic peer review and rapid publication of accepted articles

- Access all the published articles

- Re-use any of the published material for personal use and teaching without further permission

Customer Service

If you have any further queries about your subscription, please contact our customer services team on +44 (0) 2071111105 or via email at support@bmj.com.

Visit casereports.bmi.com for more articles like this and to become a Fellow 